\title{
ACTIVITY OF FAECAL FLUID OF A LEAF-CUTTING ANT TOWARD PLANT CELL WALL POLYSACCHARIDES
}

\author{
M. M. Martin, N. D. Boyd, M. J. Gieselmann, and R. G. Silver \\ The Departments of Chemistry and Zoology, University of Michigan, Ann Arbor, Michigan 48104, \\ U.S.A.
}

(Received 15 April 1975)

\begin{abstract}
The faecal fluid of the leaf-cutting ant, Atta colombica tonsipes, has been shown to contain enzymes active in the degradation of pectin, sodium polypectate, xylan, and carboxymethylcellulose. In addition, glycosidase activity has been detected in the faecal fluid using various naturally occurring disaccharides and synthetic $p$-nitrophenyl glycosides as substrates. The importance of these enzymes in the symbiosis between $A$. c. tonsipes and its food fungus is discussed, with particular emphasis on the rôle of the pectin-degrading enzymes.
\end{abstract}

\section{INTRODUCTION}

ANTs of the genus Atta culture a fungus on fresh plant material collected from the surrounding forest. In common with other attine species, Atta workers characteristically defaecate on substrate which they are preparing for incorporation into their fungus gardens (WeBER, 1972). In our previous studies of the biochemical basis for this spectacular symbiosis, we established that the faecal fluid of the attine ants contains high levels of enzymes active in the degradation of protein, chitin, and starch (MARTIN and Martin, 1970a, b, 1971; Martin et al., 1973). We have also demonstrated that the fungus cultured by Atta grows rapidly in a synthetic culture medium only if a mixture of amino acids is provided as the nitrogen source, but very slowly when proteins or polypeptides are the only available sources (MARTIN and Martin, 1970b). We have further shown that growth is greatly accelerated in a medium containing polypeptides if the ants' faecal fluid, or the proteinases present in the faecal fluid, are added to the culture medium (Boyd and Martin, 1975). We were thus led to suggest that the faecal enzymes serve a crucial adaptive function in the ants' fungus-culturing activities by catalysing the degradation of proteins present in the leaf tissue on which the fungus is cultured, thus facilitating rapid fungal growth.

The biochemical basis for this symbiosis is further examined in this paper by determining the activity of the faecal fluid of Atta colombica tonsipes toward the principal structural polysaccharides present in the tissues of higher plants.

\section{MATERIALS AND METHODS}

Faecal fluid

Faecal fluid was obtained either by dissection (MARTIN and Martin, 1970a) or by inducing the ants to defaecate using the ether immersion technique developed by BOYD and MARTIN (1975).

\section{Activity toward polymeric substrates}

Activity of faecal fluid toward citrus pectin, sodium polypectate (NaPP), soluble starch, larchwood xylan, and carboxymethylcellulose (CMC) was determined by measuring the liberation of reducing groups by the use of the 3,5-dinitrosalicylic acid reagent (BERNFELD, 1955). Samples of faecal fluid were incubated for $30 \mathrm{~min}$ at $37^{\circ} \mathrm{C}$ with $0.5 \mathrm{ml}$ of a substrate solution $(0.5 \%)$ in $0.1 \mathrm{M}$ acetate buffer (pH 5.5). The incubation was terminated by adding $1 \mathrm{ml}$ of the 3,5-dinitrosalicylic acid reagent and heating in a boiling water-bath for $5 \mathrm{~min}$. Then $1.5 \mathrm{ml}$ of water was added, the mixture centrifuged if necessary, and the O.D. at $540 \mathrm{~nm}$ determined. Controls were run with boiled, inactivated samples of faecal fluid.

Activity toward pectin and NaPP was also determined by measuring the reduction in viscosity of $5 \mathrm{ml}$ of a solution of substrate (pectin, $2.4 \%$; $\mathrm{NaPP}, 4 \%$ ) in $0.01 \mathrm{M}$ citrate ( $\mathrm{pH} \mathrm{5.2)}$ following the addition of an aliquot of faecal fluid. Viscosity was determined at $30^{\circ} \mathrm{C}$ using a Cannon-Fenske viscosimeter (size 300).

Pectin methylesterase activity was assayed at $25^{\circ} \mathrm{C}$ by a modification of the continuous titration method of Kertesz (1951). A quantity of faecal fluid derived from 10 to 15 ants was added to $4 \mathrm{ml}$ of a $0.5 \%$ solution of citrus pectin in $0.1 \mathrm{~N} \mathrm{KCl}$ which had been adjusted to $\mathrm{pH} 6.6$ with $0.1 \mathrm{~N}$ $\mathrm{NaOH}$. The $\mathrm{pH}$ of the incubation mixture was maintained at 6.6 by the automatic addition of 0.01 $\mathrm{N} \mathrm{NaOH}$ over a period of $10 \mathrm{~min}$. The rate of addition of base was linear during this time interval. The initial rate of the enzymatic hydrolysis was calculated from this linear portion. The initial 
rates were proportional to the amount of faecal fluid assayed.

\section{Activity toward low molecular weight substrates}

Glycosidase activity of the faecal fluid was determined at $30^{\circ} \mathrm{C}$ by following the release of $p$-nitrophenol from $p$-nitrophenyl- $\alpha$-D-glucoside, $p$-nitrophenyl- $\beta$-D-glucoside, $\quad p$-nitrophenyl- $\alpha$-Dgalactoside, and $p$-nitrophenyl- $\beta$-D-galactoside. Assay mixtures consisted of $0.75 \mathrm{ml}$ of substrate solution $(3.32 \mathrm{mM}), \quad 0.75 \mathrm{ml}$ of $0.2 \mathrm{M}$ acetate

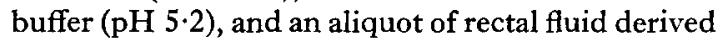
from a known number of ants. The reaction was terminated by the addition of $0.5 \mathrm{ml}$ of $1.0 \mathrm{M}$ $\mathrm{NH}_{4} \mathrm{OH}-\mathrm{NH}_{4} \mathrm{Cl}$ buffer ( $\mathrm{pH} 9.8$ ), and the absorbance read at $420 \mathrm{~nm}$.

The activity of the faecal fluid toward the disaccharides, maltose, cellobiose, turanose, trehalose, and sucrose was determined by measuring the rate of disappearance of these substances when incubated with faecal fluid. The assay mixture consisted of $10 \mu \mathrm{l}$ of a substrate solution ( $73 \mathrm{mM}$ in substrate and $139 \mathrm{mM}$ in inositol) plus $10 \mu 1$ of a solution of faecal fluid (from 10 ants) in $0.1 \mathrm{M}$ phosphate buffer ( $\mathrm{pH} 6 \cdot 0)$. Samples were incubated for $2 \mathrm{hr}$ at $37^{\circ} \mathrm{C}$ in capped Mini-Aktor tubes (Applied Science Laboratories). The reaction was terminated by immersing the reaction tube in boiling water for several minutes. Samples were prepared for GLC analysis by placing them in a desiccator over phosphorus pentoxide at reduced pressure (to remove water), then silylating them with $250 \mu \mathrm{l}$ of Sil-Prep (Applied Sciences Laboratories) at $65^{\circ} \mathrm{C}$ for $1.5 \mathrm{hr}$. The amount of substrate present initially and after incubation was determined by gas-liquid chromatography on a $3 \%$ SE-30 column $\left(175\right.$ to $290^{\circ} \mathrm{C} ; 8^{\circ} \mathrm{C} / \mathrm{min}$; lower temperature interval, $7 \mathrm{~min}$; upper temperature interval, $2 \mathrm{~min}$ ). The per cent of substrate remaining after incubation was calculated from the ratios of the areas of the peaks due to substrate and inositol before and after incubation. The identity of the products of hydrolysis (glucose and fructose) was confirmed by comparison of the observed retention times with those of silylated derivatives of authentic samples.

\section{Activity toward intact leaves}

Aliquots of faecal fluid or a solution of pectinase derived from Aspergillus niger (Sigma) were applied to the surface of a lilac leaf, and the effects on the appearance of the leaf noted by microscopic examination.

\section{Fungal growth studies}

The fungus normally grown by $A$. c. tonsipes was cultured in cotton-plugged flasks at $25^{\circ} \mathrm{C}$ (rotated at $180 \mathrm{rev} / \mathrm{min}$ ) in the synthetic medium described by Robbins and Hervey (1960) and modified by MARTIN and WeBer (1969). The nitrogen source was enzymatic casein hydrolysate (Calbiochem), $10 \mathrm{~g} / 1$., and the carbon source was either soluble starch, CMC, or pectin $(20 \mathrm{gm} / 1$. for growth studies, $30 \mathrm{~g} / \mathrm{l}$. for studies of viscosity effects). The initial $\mathrm{pH}$ was adjusted to 6.4 to 6.6 by the dropwise addition of $0.5 \mathrm{~N} \mathrm{KOH}$. Flasks were inoculated with $1 \mathrm{ml}$ of a seed culture of the fungus homogenized for $10 \mathrm{sec}$ in a sterilized Waring blender. After inoculation, aliquots of faecal fluid derived from approximately 50 workers of $A$. c. tonsipes were added through Millex filter units. At the completion of the growth period, the cultures containing starch and CMC were filtered, and the recovered mycelial mats dried for $6 \mathrm{hr}$ at $60^{\circ} \mathrm{C}$, and weighed. Aliquots of medium were periodically removed from the cultures containing pectin, and the viscosities determined at $30^{\circ} \mathrm{C}$ using a Cannon-Fenske viscosimeter (size 300).

\section{RESULTS}

\section{The enzymatic activity of the faecal fluid}

The faecal fluid of $A$. c. tonsipes was found to catalyze the degradation of pectin, NaPP, starch, xylan, and CMC (Table 1). By far the highest activity was exhibited toward pectin and $\mathrm{NaPP}$, from which reducing groups were liberated at rates thirty to forty-five times greater than from the other substrates. It was also established that the activity of the faecal fluid toward these polysaccharides is undiminished even after the isolated faecal fluid had been held for $60 \mathrm{hr}$ at $25^{\circ} \mathrm{C}$ and $\mathrm{pH} 5 \cdot 65$. This finding reveals the high level of stability of the enzymes under the physiological conditions encountered in the ants' rectum, where a $\mathrm{pH}$ of 5.8 has been recorded (Boyd and MARTIN, 1975), and under the conditions likely to be encountered in the plant tissue onto which they are excreted.

Activity toward pectin and NaPP was also detected by noting the rapid decrease in the viscosities of solutions of these two substrates upon incubation with faecal fluid (Table 2). In sharp contrast to the faecal fluid of $A$. c. tonsipes, digestive fluid obtained by dissection of the midguts of workers of the three non-attine species, Formica ulkei, $F$. dakotensis, and $F$. pallidefulva nitidiventris, did not bring about the depolymerization of pectin. No reduction in the viscosity of a $2.4 \%$ pectin solution was observed after an incubation time of $1 \mathrm{hr}$ with the midgut fluid derived from 10 workers of the three Formica species examined.

The capacity of the faecal fluid of $A$. c. tonsipes to degrade pectin was also examined in cultures of the ants' fungus growing in a medium containing pectin. If faecal fluid derived from approximately 50 ants was added to the culture flask (which contained 
Table 1. Activity of faecal fluid (FF) of $A$. c. tonsipes toward pectin, NaPP, starch, xylan, and CMC*

\begin{tabular}{cccc}
\hline Sukstrate & $\begin{array}{c}\text { Number of ants } \\
\text { from which FF } \\
\text { was derived }\end{array}$ & $\begin{array}{c}\text { o. D./min./ant } \\
\left(\times 10^{3}\right)\end{array}$ & $\begin{array}{c}\text { Maltose equivalents } \\
\text { moliberated, } \\
\text { moles/min./ant } \\
\left(\times 10^{3}\right)\end{array}$ \\
\hline Pectin & 0.76 & 7.89 & 14.6 \\
, & 0.38 & 8.34 & 15.4 \\
NaI'P & 0.76 & 11.62 & 21.5 \\
" & 0.38 & 11.84 & 21.8 \\
Stärch & 26.8 & 0.243 & 0.45 \\
" & 13.4 & 0.248 & 0.46 \\
Xy:.an & 26.8 & 0.252 & 0.47 \\
" & 13.4 & 0.236 & 0.44 \\
CMc & 26.8 & 0.202 & 0.37 \\
" & 13.4 & 0.211 & 0.39 \\
\hline
\end{tabular}

* Assay mixtures were incubated for 1 hour at $37^{\circ} \mathrm{C}$. FF was obtained

by the ether immersion procedure. Blanks consisted of the normal incubation mixture plus FF which had been inactivated by boiling.

Table 2. Effect of faecal fluid (FF) of $A$, c. tonsipes on the viscosities of solutions of pectin $(2 \cdot 4 \%)$ and $\mathrm{NaPP}(4 \%)^{*}$

\begin{tabular}{cccc}
\hline Substrate & $\begin{array}{l}\text { Number of ants } \\
\text { from which FF } \\
\text { was derived }\end{array}$ & $\begin{array}{c}\text { viscosity reduction } \\
\text { after } 6 \text { minutes, } \\
(\mathrm{o})\end{array}$ & $\begin{array}{c}\text { Time for 508 } \\
\text { reduction in } \\
\text { viscosity } \\
\text { (minutes) }\end{array}$ \\
\hline Pactin & Blank & 0 & - \\
" & 5 & 18 & 30 \\
" & 10 & 43 & 13 \\
Napp & 20 & 66 & 4 \\
$"$ " & Blank & 0 & - \\
" & 5 & 41 & 5 \\
\hline
\end{tabular}

${ }^{*}$ FF was obtained by the ether immersion procedure. Viscosity measurements were conducted on 5-mI samples of substrate solution to which the FF was added. Blanks consisted of the substrate solution plus FF (from 10 ants) which had been deactivated by boiling. 
Table 3. Pectin methylesterase activity of faecal fluid (FF) of A. c. tonsipes at $25^{\circ} \mathrm{C}^{*}$

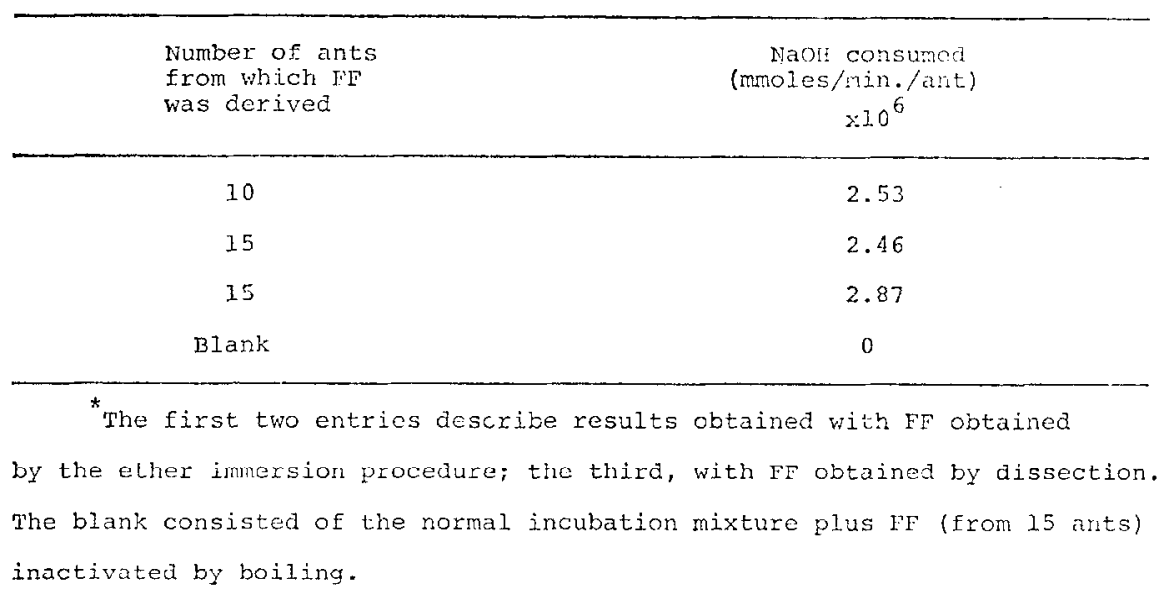

Table 4. Glycosidase activity of faecal fluid (FF) of $A$. c. tonsipes*

\begin{tabular}{|c|c|c|c|}
\hline $\begin{array}{l}\text { P-Nitrophenyl- } \\
\text { glycosido }\end{array}$ & $\begin{array}{l}\text { Number of ants } \\
\text { from which FF } \\
\text { was derived }\end{array}$ & $\begin{array}{c}\text { AO.D. } / \mathrm{min} . / \mathrm{ant} \\
\left(\times 10^{3}\right)\end{array}$ & $\begin{array}{c}\text { p-Nitrophenol } \\
\text { liberated, } \\
\text { mole/min./ant } \\
\left(\times 10^{7}\right)\end{array}$ \\
\hline$\alpha-D-G l u c o s e$ & 2.25 & 10.60 & 13.1 \\
\hline$B-D-G l u c o s e$ & 2.25 & 3.78 & 4.7 \\
\hline "t & 4.50 & 3.37 & 4.2 \\
\hline$\alpha-D-G a l a c t o s c$ & 2.25 & 4.04 & 5.0 \\
\hline B-D-Ga1uctose & 2.25 & 0.28 & 0.35 \\
\hline$"$ & 4.50 & 0.23 & 0.28 \\
\hline
\end{tabular}

* Assay mixtures were incubated at $30^{\circ} \mathrm{C}$ for periods of time varying

from 20 to 90 minutes. FF was obtained by the ether immersion procedure.

Blanks consisted of the normal incubation mixture plus FF which had been

inactivated by boiling.

$1.5 \mathrm{~g}$ of pectin dissolved in $50 \mathrm{ml}$ of medium) at the time of inoculation, an average reduction in viscosity of the medium of 63 per cent was observed after $18 \mathrm{hr}$. If the faecal fluid were omitted, no reduction in viscosity was detectable $18 \mathrm{hr}$ after inoculation.

It was also noted that the application of the ants' faecal fluid to the surface of a lilac leaf brought about the rapid maceration of the leaf tissue. That this effect is due to the capacity of the faecal fluid to degrade pectin was supported by the observation that a purified fungal pectinase from $A$. niger (Sigma) brought about similar changes in the appearance of the leaf tissue.

The faecal fluid of $A$. c. tonsipes. also contains a pectin methyl esterase (Table 3).
Glycosidase activity was detected in the faecal fluid of $A$. $c$. tonsipes using the synthetic $p$-nitrophenyl glycosides of glucose and galactose (Table 4 ), and also some naturally occurring disaccharides (Table 5). With the synthetic $p$-nitrophenyl glycosides as substrates, $\alpha$-glucosidase activity was found to be significantly higher than either $\beta$ glucosidase or $\alpha$-galactosidase activity, which were present at approximately comparable levels. $\beta$ Galactosidase activity was lower still, showing only 6 per cent of the activity of $\alpha$-galactosidase and about 2 per cent of the $\alpha$-glucosidase activity. The difference in $\alpha-$ and $\beta$-glucosidase activity is reflected in the relative tendencies of the disaccharides listed in Table 5 to undergo hydrolysis 
when incubated with faecal fluid. Maltose, trehalose, sucrose and turanose, all $\alpha$-glucosides, are hydrolysed much more rapidly than cellobiose, a $\beta$-glucoside. 'Turanose, an $\alpha(1 \rightarrow 3)$ fructosylglucoside, appears to be somewhat less rapidly hydrolysed than the other three $\alpha$-glucosides.

\section{Effects of faecul fluid on fungal growth}

The addition of sterile faecal fluid to a sterile shaken liquid culture of the ants' fungus increases the extent of growth when the carbon source in the medium is either starch or CMC (Table 6). The effects are small, a factor of 1.5 in the starch medium and 3 in the CMC medium, but significant (at the 95 per cent level in the starch medium and at the 99 per cent level in the CMC medium).

\section{DISCUSSION}

The primary objective of this study was to determine whether the faecal material of a leafcutting ant catalyses the degradation of the structural polysaccharides present in plant tissue. Clearly it does. Pectin, sodium polypectate, xylan, and cellulose, or at least the soluble derivative carboxymethylcellulose, are all degraded by the faecal fluid of $A$. c. tonsipes.

It is easy to envisage several important functions for these faecal enzymes in the fungus-culturing activities of the ants. Obviously, the degradation of the structural polysaccharides of the leaf would provide a source of readily metabolized nutrients for the newly planted fungus. Thus, rapid initial growth would be favoured at a time prior to the secretion onto the substrate of significant quantities of catabolic enzymes by the fungus. Indeed, we have noted just such a growth-enhancing effect when the fungus is cultured in a synthetic medium containing either starch or $\mathrm{CMC}$ as the primary carbon source.

A second and probably even more important rôle for the ants' faecal enzymes involves their capacity to bring about the maceration of plant tissue. Enzymes which degrade pectin and protein have

Table 5. Activity of faecal fluid (FF) of $A$. c. tonsipes toward disaccharides*

\begin{tabular}{lc} 
Substrate & $\begin{array}{l}\text { Percont substrate rcmaining } \\
\text { after 2-hour incubation at } 37^{\circ}\end{array}$ \\
\hline Maltose & 45 \\
Trehalose & 37 \\
Sucrose & 44 \\
Turanose & 62 \\
Cellobiose & 87
\end{tabular}

*Aliquots containing the FF of 10 ants were taken from a sample of

Fl obtained by the ether immersion procedure, and added to each substrate solution.

Table 6. The effect of faecal fluid (FF) from $A$. c. tonsipes on the growth of the fungus when cultured in synthetic media*

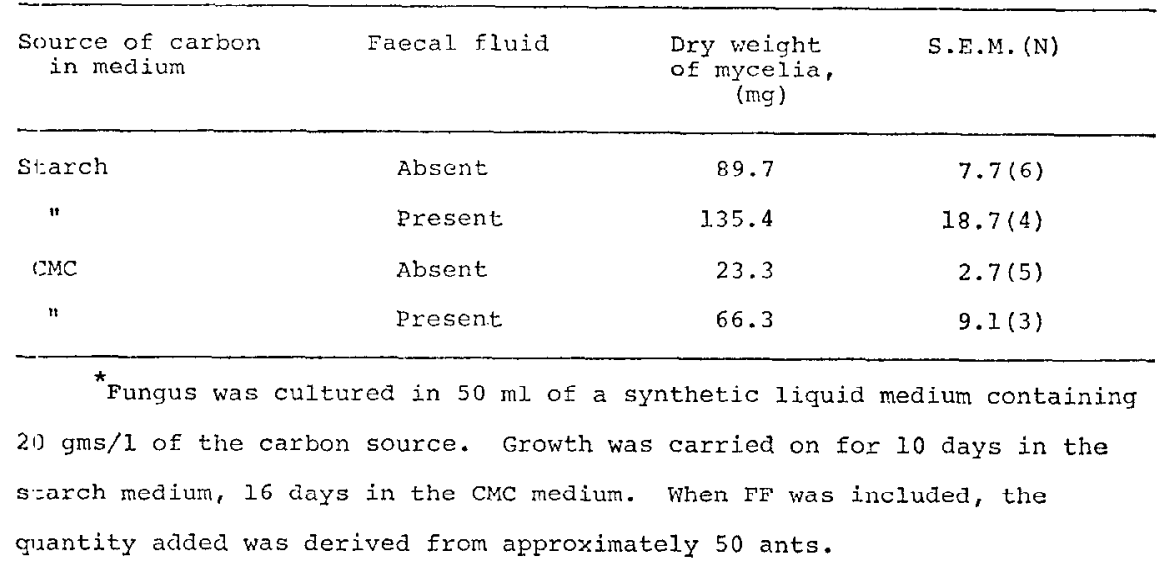


been implicated in the process of tissue maceration by pathogenic fungi as well as by some insects (Bateman and Millar, 1966; Talmadge and Albersheim, 1969; KING, 1973). Both of these types of enzymes are present at high levels in the faecal material of leaf-cutting ants. During the initial stages of vegetative growth by a fungus on plant tissue, the maceration process is critical in permitting the initial invasion of the tissue by the hyphae and in facilitating the subsequent ramification of the fungus within the tissue. In addition, the maceration of the plant tissue would improve the access of other catabolic enzymes, particularly the proteinases (BOYD and MARTIN, 1975), to potential substrates contained within the leaf. That the faecal enzymes are performing such a function when leaf-cutting ants defaecate upon substrate prior to incorporating it into their gardens is supported by two observations. First, we have observed directly the maceration of leaf tissue by the ants' faecal material. Second, we have noted that the degradation of pectin in a synthetic culture medium proceeds very rapidly when some of the ants' faecal material is included, but very slowly when none is present.

Enzymes which degrade pectin are commonly produced by micro-organisms and herbivores which consume the tissues of higher plants. A pectinase has been reported in the seed-gathering ant, Veromessor pergandei (WENT et al., 1972), but none has been detected in the three species of Formica which we examined. Since most ants are predators or scavengers and make little use of plant tissue in their diets, the secretion of enzymes active in the degradation of plant cell wall polysaccharides would not be expected to be a common trait of this family. The diet of the attine ants does not include pectin, xylan, or cellulose. It is doubtful that pectic substances occur in fungal cell walls. Furthermore, since the attine ants feed only upon the fluid material contained within the mycelium of the fungus which they cultivate (WEBER, 1972), structural polysaccharides would not be ingested by them in any event. The presence of enzymes active in the degradation of pectin, xylan and cellulose in the digestive fluids of the attine ants is, therefore, noteworthy, and raises anew the question of the origin of these enzymes. Are they digestive enzymes secreted by the ants, microbial enzymes produced by endosymbionts, or fungal enzymes present in the fluid within the hyphae upon which the ants feed?
Finally, it is interesting to note that many pectinases are inhibited by phenols and their oxidation products (BATEMAN and Millar, 1966). It would be interesting to establish whether the leaf-cutting ants avoid foraging for plants high in phenols or other potent enzyme inhibitors.

Acknowledgements-We wish to thank the National Science Foundation for a grant (No. GB-31581) which supported this work. We also wish to thank Dr. JoAN S. MARTIN and Mr. Howard E. Liss for their technical assistance.

\section{REFERENCES}

Bateman D. F. and Millar R. L. (1966) Pectic enzymes in tissue degradation. A. Rev. Phytopath. 4, 119-146. Bernfeld P. (1955) Amylases, $\alpha$ and $\beta$. In Methods of Enzymology (Ed. by Colowick S. P. and KaplaN N. O.), 1, 149-150. Academic Press, New York.

Boyd N. D. and Martin M. M. (1975) Faecal proteinases of the fungus-growing ant, Atta texana: properties, significance and possible origin. Insect Biochem. 5, 619-635.

Kertesz Z. I. (1951) The Pectic Substances, pp. 362-363. Interscience, New York.

KING E. E. (1973) Endo-polymethylgalacturonase of boll weevil larvae, Anthonomus grandis: an inititiator of cotton flower bud abscission. F. Insect Physiol. 19, 2433-2437.

Martin J. S. and Martin M. M. (1970a) The presence of protease activity in the rectal fluid of attine ants. f. Insect Physiol. 16, 228-232.

Martin M. M., Gieselmann M. J., and Martin J. S. (1973) Rectal enzymes of attine ants. $\alpha$-Amylase and chitinase. \%. Insect Physiol. 19, 1409-1416.

Martin M. M. and MarTin J. S. (1970b) The biochemical basis for the symbiosis between the ant, Atta colombica tonsipes, and its food fungus. $\mathcal{F}$. Insect Physiol. 16, 109-119.

Martin M. M. and Martin J. S. (1971) The presence of protease activity in the rectal fluid of primitive attine ants. F. Insect Physiol. 17, 1897-1906.

Martin M. M. and Weber N. A. (1969) The celluloseutilizing capabilities of the fungus cultured by the ant Atta colombica tonsipes. Ann. ent. Soc. Am. 62, 1386-1387.

Robbins W. J. and Hervey A. (1960) Light and development of Poria ambigua. Mycologia 52, 231-247.

Talmadge K. W. and Albersheim P. (1969) Plant cell wall polysaccharide-degrading enzymes of Melanoplus bivitatus. F. Insect Physiol. 15, 2273-2284.

WebER N. A. (1972) Gardening ants, the Attines. Mem. Am. phil. Soc. 92, 1-146.

Went F. W., Wheeler J., and Wheeler G. C. (1972) Feeding and digestion in some ants (Veromessor and Manica). BioSci. 22, 82-88. 